\title{
PROFITABILITAS PENERBANGAN RUTE JAKARTA - MAKASSAR PP MENGGUNAKAN PESAWAT GARUDA B737-800NG TAHUN 2019
}

\author{
* Mochamad Arif Hernawan ${ }^{1}$, Muhammad Yoga Pramudya ${ }^{2}$, Tito Warsito ${ }^{3}$ \\ 1,2,3 Institut Transportasi dan Logistik Trisakti, Jakarta, Indonesia
}

*Email Korespondensi:

arifhernawan1112@gmail.com

\section{ARTIKEL INFORMASI}

Diterima:

25 Juni 2021

Direvisi:

12 Juli 2021

Dipublikasi:

22 Juli 2021

\section{ABSTRAK}

PT. Garuda Indonesia merupakan maskapai penerbangan terbesar di Indonesia yang menguasai penerbangan domestic dengan kelas pelayanan full service. Pada tahun 2019 mengoperasikan penerbangan Rute CGK - UPG PP dengan menggunakan tipe pesawat B737-800NG. Adapun permasalahan dalam skripsi ini adalah bagaimana Profitabilitas Untuk Rute Jakarta - Makassar PP Tahun 2019. Adapun metode analisis data yang digunakan adalah Pertama Penelitian Kepustakaan (Library research). Kedua metode analsis data dengan menggunakan analisis data Deskriptif kuantitatif, untuk menjelaskan data data yang sudah ada mengenai analsis pasar penerbangan Rute CGK - UPG PP dengan menggunakan tipe pesawat B737-800NG data penumpang actual yang diperoleh 186.266 untuk kurun waktu 3 bulan sehingga rata-rata per bulan berdasarkan analisis sebesar 93.133. Dari hasil 849, perhitungan Rute CGK - UPG dengan menggunakan B737-800NG memperoleh Revenue sebesar US\$12.262.505/ 3bulan, Cost sebesar US\$ 11.062.896,71/3bulan, Profit sebesar US\$ 1.210.008,29. Dari hasil perhitungan Rute UPG - CGK dengan menggunakan B737-800NG memperoleh Revenue sebesar US\$ 14.694.363, Cost sebesar US\$ 13.844.662,34, Profit sebesar US\$ 849.700,66. Maka di ketahui penerbangan rute CGK - UPG PP menggunakan tipe pesawat B737-800NG adalah Profit.

Kata Kunci: Profitabilitas, Pesawat, CGK - UPG PP

\section{PENDAHULUAN}

Transportasi udara merupakan salah satu penunjang kegiatan bisnis perpindahan baik barang, orang maupun binatang untuk menjangkau antar pulau dan daerah-daerah di Indonesia bahkan hingga ke daerah terpencil. Waktu tempuh perjalanan yang lebih singkat menjadi pilihan utama penumpang dalam menggunakan transportasi udara dibandingkan moda transportasi lain. PT. Garuda Indonesia merupakan maskapai penerbangan terbesar di Indonesia yang menguasai penerbangan domestic dengan kelas pelayanan full service. Boeing 737-800NG adalah pesawat yang banyak digunakan untuk angkutan komersial untuk penerbangan jarak dekat. Pertama kali dibuat pada tahun 2001, dan resmi mengudara pada tahun 2007, Boeing737-800NG dioperasikan pertama kali oleh maskapai penerbangan asal Indonesia yaitu Garuda 
Indonesia tahun 2007. Rute Jakarta - Makassar ini telah dioperasikan sejak lama puluhan tahun yang lalu. Potensi pasar yang dimiliki rute Jakarta - Makassar sangat terjamin untuk dijadikan tempat tujuan penerbangan, namun maskapai Garuda Indonesia masih belum maksimal dalam menguasai pasarnya jika dibandingkan dengan pesaingnya.

Maka dengan demikian rute Jakarta - Makassar sangat berdampak positif bagi PT. Garuda sebab Makassar memiliki lokasi yang sangat strategis dan memiliki daya tarik wisatawan yang sangat tinggi. Pesawat Garuda B737-800NG dijadikan pilihan oleh PT.Garuda karena memiliki kapasitas seat yang cukup besar yaitu 162Y/12C, dan dengan frekuensi yang lebih banyak di bandingkan dengan para pesaingnya seperti Liion Air , Batik Air dan sebagainya, namun dalam kenyataannya perolehan market share Garuda Indonesia hanya mendapatkan 24\% dibandingkan dengan Lion Air yang marketsharenya 28\%, Makassar adalah Ibu Kota Provinsi Sulawesi Selatan yang juga terkenal dengan pesona wisata alam dan sejarah. Sehingga Kota Makassar banyak dipilih oleh wisatawan untuk tempat berwisata. Selain pusat bisnis untuk wilayah Sulawesi Selatan dan sekitarnya, juga merupakan pusat kota transit untuk penerbangan bagian Indonesia Timur lainnya. Hal ini bisa dilihat dari jumlah total penumpang penerbangan domestic yang datang, berangkat, dan transit mengalami kenaikan sebesar 15,94 persen dari 468.630 orang pada bulan September 2020 menjadi 543.348 orang pada bulan Oktober 2020, pertumbuhan industri, bisnis, investasi, jumlah penerbangan, dan sebagainya.

Dari latar belakang dan pembatasan masalah yang telah dikemukakan, maka perumusan masalah penelitian dapat dirumuskan sebagai berikut : 1) Bagaimana Pangsa Pasar Pada Rute Penerbangan Jakarta Makassar PP Dengan Menggunakan Pesawat GA B737-800NG Pada Tahun 2019, 2) Bagaimana Cost dan Revenue Untuk Penerbangan Jakarta - Makassar PP Dengan Menggunakan Pesawat GA B737-800NG Pada Tahun 2019, 3) Bagaimana Profitabilitas Untuk Rute Jakarta - Makassar PP Menggunakan Pesawat GA B737800NG Pada Tahun 2019. tujuan penelitian ini adalah : 1)Untuk Mengetahui Pangsa Pasar Untuk Penerbangan Jakarta - Makassar PP Dengan Menggunakan Pesawat GA B737-800NG Pada Tahun 2019, 2) Untuk Mengetahui Cost Dan Revenue Penerbangan Jakarta - Makassar PP Dengan Menggunakan Pesawat GA B737800NG Pada Tahun 2019, 3) Untuk Mengetahui Profitabilitas Untuk Rute Jakarta - Makassar PP Dengan Menggunakan Pesawat GA B737-800NG Pada Tahun 2019.

\section{KAJIAN PUSTAKA}

Laba merupakan elemen yang paling menjadi perhatian pemakai karena angka laba diharapkan cukup kaya untuk mempresentasi kinerja perusahaan secara keseluruhan. Akan tetapi, teori akuntansi sampai saaat ini belum mencapai dalam pemaknaan dan pengukuran laba. Menurut (Medias, 2018) profit secara istilah adalah perbedaan yang timbul ketika total pendapatan (total revenue) suatu perusahaan lebih besar dari biaya total (total cost). Profit dalam kegiatan operasional perusahaan merupakan elemen yang kepenting untuk menjamin kelangsungan hidup perusahaan pada masa yang akan datang. Keberhasilan perusahaan dapat dilihat dari kemampuan perusahaan untuk dapat bersaing dipasar. Setiap perusahaan mengharapkan profit yang maksimal. Laba merupakan alat ukur utama kesuksesan suatu perusahaan. Profitabilitas adalah hasil akhir dari sejumlah kebijakan dan keputusan yang dilakukan oleh perusahaan. Menurut Sutrisno (2009, p.16) "Profitabilitas adalah kemampuan perusahaan dalam menghasilkan keuntungan dengan semua modal yang bekerja didalamnya.

Profitabilitas menurut Sofyan Syafri Harahap (2009, p.304) adalah Menggambarkan kemampuan perusahaan mendapatkan laba melalui semua kemampuan dan sumber daya yang ada seperti kegiatan penjualan, kas, modal, jumlah karyawan, jumlah cabang perudahaan, dan lain sebaginya. Sedangkan menurut (Brigham, 2009) "Profitabilitas merupakan hasil akhir dari sejumlah kebijakan dan keputusan yang dilakukan oleh perusahaan. Tujuan akhir yang ingin dicapai suatu perusahaan yang terpenting adalah memperoleh laba atau profit yang maksimal. Untuk mengukur tingkat keuntungan suatu perusahaan digunakan rasio profitabilitas. Menurut (Kasmir, 2011)"Rasio Profitabilitas merupakan rasio untuk menilai kemampuan perusahaan dalam mencari keuntungan".

Rasio profitabilitas menurut Brigham dan Houston (2009, p.196) "Sekelompok rasio yang menunjukan gabungan efek - efek dari likuiditas, manajemen aktiva, dan utang pada hasil operasi. Rasio ini meliputi margin laba atas penjualan, rasio kemampuan dasar untuk menghasilkan laba, tingkat pengembalian atas total aktiva, dan tingkat pengembalian ekuitas saham biasa.

Rasio profitabilitas menurut (Weston, Fred dan Thomas, 2010) adalah mengukur efektivitas manajemen berdasarkan hasil pengembalian yang dihasilkan dari penjualan dan investasi. Profitability Index merupakan 
rasio nilai sekarang dari arus Kas bebas masa depan terhadap pengeluaran awal (Arthur, 2005). Rumus umum dari Profitability Index (Ross et.al.,2008) : PI = PV of cash flows subsequent to initial investment / Initial Investment. Menurut (Sujarweni, 2019), biaya dalam arti luas adalah pengorbanan sumber ekonomi yang diukur dalam satuan uang dalam usahanya untuk mendapatkan sesuatu untuk mencapai tujuan tertentu baik yang sudah terjadi dan belum terjadi / baru direncanakan. Menurut (Dewi, S. P., Kristanto, S. B., \& Sermawan, 2015) biaya adalah sumber daya yang dikorbankan atau dilepaskan untuk mencapai tujuan tertentu di masa depan. Pengertian biaya menurut (Mulyadi, 2016) "Biaya adalah pengorbanan sumber ekonomis yang diukur dalam satuan uang, yang telah terjadi, sedang terjadi, atau kemungkinan akan terjadi untuk tujuan tertentu".

Menurut (Mulyadi, 2016), biaya dapat digolongkan menurut berikut : 1) Penggolongan Biaya Menurut Obyek Pengeluaran; Dalam cara ini, nama obyek pengeluaran merupakan dasar Penggolongan biaya. Misalnya nama obyek pengeluaran adalah bahan bakar, maka semua pengeluaran yang berhubungan dengan bahan bakar disebut biaya bahan bakar.

Penggolongan Biaya Menurut Fungsi Pokok Dalam Perusahaan ; Dalam perusahaan manufaktur ada tiga fungsi pokok, yaitu fungsi produksi, fungsi pemasaran, dan fungsi administrasi dan umum. Oleh karena itu dalam perusahaan manufaktur, biaya dapat dikelompokkan menjadi tiga kelompok : 1) Biaya Produksi merupakan biaya-biaya yang terjadi untuk mengolah bahan baku menjadi produk jadi yang siap untuk dijual. Menurut obyek pengeluarannya, biaya produksi dapat dibagi menjadi : biaya bahan baku, biaya tenaga kerja, dan biaya overhead pabrik., 2) Biaya Pemasaran merupakan biaya-biaya yang terjadi untuk melaksanakan kegiatan pemasaran produk, 3) Biaya Administrasi dan Umum merupakan biaya-biaya yang terjadi untuk mengkoordinasi kegiatan produksi dan pemasaran produk. Penggolongan Biaya Menurut Hubungan Biaya dengan Sesuatu yang dibiayai. Dalam hubungannya dengan sesuatu yang dibiayai, biaya dapat dikelompokkan menjadi dua golongan ; 1) Biaya Langsung (direct cost), yaitu biaya yang terjadi, yang penyebab satu-satunya adalah karena adanya sesuatu yang dibiayai, 2) Biaya Tidak Langsung (indirect cost), yaitu biaya yang terjadinya tidak hanya disebabkan oleh sesuatu yang dibiayai. Biaya tidak langsung dalam hubungannya dengan produk disebut dengan istilah biaya produksi tidak langsung atau biaya overhead pabrik, 3) Penggolongan Biaya Menurut Perilakunya Dalam Hubungannya dengan Perubahan Volume Kegiatan Menurut cara penggolongan ini, biaya dapat digolongkan menjadi empat, diantaranya Biaya variabel, adalah biaya yang jumlah totalnya berubah sebanding dengan perubahan volume kegiatan, 1) Biaya semi variabel, adalah biaya yang berubah tidak sebanding Dengan perubahan volume kegiatan. Dalam biaya semi variabel Mengandung unsur biayatetap dan unsur biaya variabel, 2) Biaya semifixed, adalah biaya yang tetap untuk tingkat volume kegiatan tertentu dan berubah jumlah yang konstan pada volume produksi tertentu, 3) Biaya tetap, adalah biaya yang tetap jumlah totalnya dalam kisar volume kegiatan tertentu. Contohnya: biaya gaji direktur produksi.

Menurut (Pamungkas, 2019), tariff bagi konsumen merupakan segala bentuk biaya moneter yang dikorbankan oleh konsumen untukmemperoleh, memiliki, memanfaatkan sejumlah kombinasi dari barang beserta pelayanan suatu produk. Menurut (Duari, 2018), fare adalah jumlah biaya yang dibebankan oleh pengangkut bagi penumpang dan barang bawaannya yang diterbitkan secara umum kepada public berdasarkan jenis kelas yang tertera untuk mendapatkan layanan sesuai dengan kelas dan rute yang ditempuh. Faktor Penetapan Tarif, Menurut (Amin, 2013), dalam menetapkan tarif, faktor-faktor yang berpengaruh dalam penetapan tariff tersebut yaitu: Biaya menjadi batas bawah, Tarif pesaing dan tariff barang pengganti menjadi titik orientasi yang perlu dipertimbangkan perusahaan, Penilaian pelanggan terhadap tampilan produk yang unik dari penawaran perusahaan menjadi batas atas tariff harga.

Menurut Ussinova et al (2018), frekuensi penerbangan adalah jumlah penerbangan untuk setiap bulan dari asal dan tujuan yang dioperasikan oleh perusahaan penerbangannya. Faktor Yang Mempengaruhi Frekuensi Penerbangan, Menurut, Pai (2010) faktor - faktor ini adalah faktor yang memainkan peranan penting dalam menentukan frekuensi penerbangan. Menurut Drs M.N. Nasution,M.S.Tr.,APU (2008:201) sistem transportasi udara meliputi atas alat angkut (vehicles), yaitu pesawat terbang, jalur penerbangan (ways) yaitu jaringan penerbangan, air traffic control, telekomunikasi dan navigasi, lampu landasan, dan meteorology penerbangan. Sistem transportasi udara juga sesuatu yang berada di darat yaitu landasan taxiway, apron terminal penumpang dan barang, listrik dan air, pemadam kebakaran, ground handling equitment, hangar, kesehatan penerbangan, perkantoran, jaringan jalan raya, pemagaran bendera, dan pendukung lainnya.

Bandar udara adalah sebagian tanah yang terdapat diwilayah Bandar Udara dipakai untuk keperluan tinggal landas (take-off) dan mendarat (landing) secara tempat bergerak (ground movement) pesawat udara. Kecuali fasilitas pendaratan dan tinggal landas (yang terdiri dari landasan, taxiway, lampu penerangan landasan, dan lain-lain) bagi pelayanan atas radar, ILS (instrument lanig system), NDB (non directional 
beacon), DVOR (distance very high frequency omni range), DME (distance meansuring equipment), jasa meteorology, fasilitas parker pesawat udara (apron), hangar, fasilitas perawatan pesawat, fasilitas pengisian bahan bakar, fasilitas jasa boga (catering). Pesawat udara yang baru terus memasuki dunia penerbangan dengan kemampuannya yang lebih besar. Hal ini, bukan saja lebih banyak jumlah penumpang yang harus dilayani, tetapi persyaratan fasilitas penerbangan yang diperlukan juga lebih tinggi. Panjang dan daya dukung landasan harus ditambah, peralatan navigasi juga harus ditingkatkan dengan teknologi yang lebih canggih, ruangtunggu dan peralatan pelayanan bagasi harus ditambah, tempat parker perlu di perluas, dan fasilitas lain perlu dibuka.

Kemampuan bandara dapat dihitung berdasarkan jumlah tinggal landas (take-off) dan mendarat (landing) pada jam-jam sibuk (peak hours). Batas yang wajar pada kepadatan dalam jam sibuk adalah 50 - 60 pesawat yang tinggal landas dan mendarat dalam keadaan udara cerah atau 30 - 40 pesawat jika tinggal landas dan mendarat dengan bantuan peralatan dalam cuaca buruk. Kalau udara mempunyai dua landasan yang parallel jumlah ini dapat meningkat hamper dua kali.

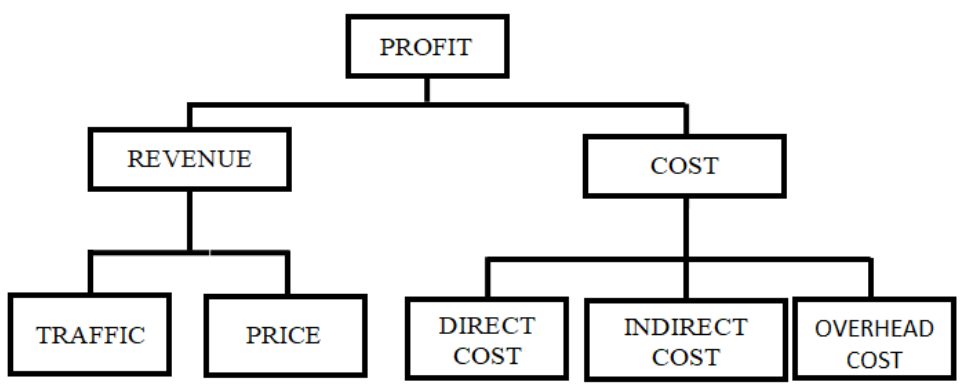

Gambar 1. Kerangka berfikir

\section{METODE}

Penelitian ini dilakukan untuk mengetahui suatu profitabilitas rute Jakarta - Makassar menggunakan pesawat garuda B737-800NG, maka dalam pelaksanaan penelitian ini akan menggunakan pendekatan jenis penelitian kuantitatif yang dilaksanakan melalui pengumpulan data dari internet karena dampak pandemic covid 19 penulis mengalami keterbatasan dalam mencari data. Sumber data yang digunakan dalam penelitian ini adalah data primer dan data sebenarnya yaitu data sekunder. Teknik analisis data yang digunakan oleh penulis adalah penelitian kuantitatif.

\section{HASIL DAN PEMBAHASAN}

Adapun data statistik airlines yang melakukan perjalanan dengan rute Jakarta - Makassar sebagai berikut ini :

Tabel 1. Frekuensi Garuda rute CGK-UPGTahun 2019

\begin{tabular}{|c|c|c|c|}
\hline $\begin{array}{l}\text { AIRLINE } \\
\text { S }\end{array}$ & $\begin{array}{c}\text { TYPE } \\
\text { AIRCRAFT }\end{array}$ & $\begin{array}{c}\text { DAYS } \\
\text { OPERATION }\end{array}$ & SCHEDULLE \\
\hline GA 616 & B737-800 & $1,2,3,4,5,6,7$ & CGK-UPG \\
\hline GA 608 & B737-800 & $1,2,3,4,5,6$ & CGK-UPG \\
\hline GA 604 & B737-800 & $1,2,3,4,5,6,7$ & CGK-UPG \\
\hline GA 642 & B737-800 & $1,2,3,4,5,6,7$ & CGK-UPG \\
\hline GA 650 & B737-800 & $1,3,5,6$ & CGK-UPG \\
\hline GA 612 & B737-800 & $1,2,3,4,6$ & CGK-UPG \\
\hline GA 640 & B737-800 & $1,2,4,6$ & CGK-UPG \\
\hline GA 654 & B737-800 & $1,3,4,6$ & CGK-UPG \\
\hline
\end{tabular}

Sumber : https://www.wego.co.i 
Tabel 2. Frekuensi Garuda rute UPG-CGK Tahun 2019

\begin{tabular}{cccc}
\hline \multirow{2}{*}{ AIRLINES } & $\begin{array}{c}\text { TYPE } \\
\text { AIRCRAFT }\end{array}$ & $\begin{array}{c}\text { DAYS } \\
\text { OPERATION }\end{array}$ & SCHEDULLE \\
\hline GA 616 & B737-800 & $1,2,3,4,5,6,7$ & UPG-CGK \\
\hline GA 608 & B737-800 & $1,2,3,4,5,6$ & UPG-CGK \\
\hline GA 604 & B737-800 & $1,2,3,4,5,6,7$ & UPG-CGK \\
\hline GA 642 & B737-800 & $1,2,3,4,5,6,7$ & UPG-CGK \\
\hline GA 650 & B737-800 & $1,3,5,7$ & UPG-CGK \\
\hline GA 612 & B737-800 & $1,2,3,4,6$ & UPG-CGK \\
\hline GA 640 & B737-800 & $1,2,4,6$ & UPG-CGK \\
\hline GA 654 & B737-800 & $1,3,4,7$ & UPG-CGK \\
\hline
\end{tabular}

Sumber : https://www.wego.co.id

Berdasarkan data yang peneliti dapatkan dari web www.wego.co.id pada tabel 4.1 Frekuensi airlines yang beroperasi pada tahun 2019 rute CGK-UPG PP Garuda Indonesia airlines dengan menggunakan tipe pesawat B737-800NG dengan rata-rata frekuensi 6kali sehari pada hari-hari tertentu sampai 7x (dalam seminggu ada 2 hari beroperasi 7 kali) yaitu hari senin dan sabtu, sehingga total frekuensinya 44x dalam seminggu.

PT. Garuda Indonesia melakukan penerbangan rute CGK - UPG dalam seminggu sebanyak 44kali yaitu pada hari senin, selasa, rabu, kamis, jumat, sabtu, dan minggu dengan menggunakan tipe pesawat B737$800 \mathrm{NG}$, sehingga total frekuensi untuk tiga bulan adalah 578 kali ditambah extra 3 bulan sebesar 29 kali, jadi total frekuensi 607 kali .

Tabel 3. Frekuensi Lion Air rute CGK-UPG Tahun 2019

\begin{tabular}{cccc}
\hline AIRLINES & TYPE AIRCRAFT & DAYS OPERATION & SCHEDULLE \\
\hline JT 872 & B737-800 & $1,2,3,4,5,6,7$ & CGK-UPG \\
\hline JT 874 & B737-800 & $1,2,3,4,5,6,7$ & CGK-UPG \\
\hline JT 772 & B737-800 & $1,2,3,4,5,6,7$ & CGK-UPG \\
\hline JT 994 & B737-800 & $1,2,3,4,5,6,7$ & CGK-UPG \\
\hline JT 778 & B737-800 & $1,2,3,4,5,6,7$ & CGK-UPG \\
\hline JT 892 & B737-800 & $1,2,3,4,5,6,7$ & CGK-UPG \\
\hline
\end{tabular}

Sumber : https://www.wego.co.id

Tabel 4. Frekuensi Lion Air rute UPG-CGK Tahun 2019

\begin{tabular}{cccc}
\hline AIRLINES & TYPE AIRCRAFT & DAYS OPERATION & SCHEDULLE \\
\hline JT 872 & B737-800 & $1,2,3,4,5,6,7$ & UPG-CGK \\
\hline JT 874 & B737-800 & $1,2,3,4,5,6,7$ & UPG-CGK \\
\hline JT 772 & B737-800 & $1,2,3,4,5,6,7$ & UPG-CGK \\
\hline JT 994 & B737-800 & $1,2,3,4,5,6,7$ & UPG-CGK \\
\hline JT 778 & B737-800 & $1,2,3,4,5,6,7$ & UPG-CGK \\
\hline JT 892 & B737-800 & $1,2,3,4,5,6,7$ & UPG-CGK \\
\hline
\end{tabular}

Berdasarkan data yang peneliti dapatkan dari web www.wego.co.id pada tabel 4.3 Frekuensi airlines Lion Air yang beroperasi pada tahun 2019 rute CGK-UPG PP Perkembangan Lion Air seiring dengan laju perkembangan ekonomi, untuk rute CGK-UPG. Lion Air melakukan penerbangan rute CGK-UPG dalam seminggu sebanyak 42 kali yaitu pada hari senin, selasa, rabu, kamis, jumat, sabtu, dan minggu dengan menggunakan tipe pesawat B737-800NG, sehingga total frekuensi untuk tiga bulan 42/7x92 hari adalah 552 kali. Dalam pembahasan ini menggunakan tipe pesawat B737-800NG dengan asumsi melakukan penerbangan dengan jumlah frekuensi yang sama yaitu sebanyak 42 kali dalam seminggu atau $552 \mathrm{flight} / 3$ bulan. Demikian juga untuk penerbangan Lion Air rute UPG-CGK sama. 
Tabel 5. Frekuensi Batik Air rute CGK-UPG Tahun 2019

\begin{tabular}{cccc}
\hline AIRLINES & TYPE AIRCRAFT & DAYS OPERATION & SCHEDULLE \\
\hline ID 6198 & B737-800 & $1,2,3,4,5,6,7$ & CGK-UPG \\
\hline ID 6182 & B737-800 & $1,2,3,4,5,6,7$ & CGK-UPG \\
\hline ID 6236 & B737-800 & $1,2,3,4,5,6,7$ & CGK-UPG \\
\hline ID 6296 & B737-800 & $1,2,3,4,5,6,7$ & CGK-UPG \\
\hline ID 6266 & B737-800 & $1,2,3,4,5,6,7$ & CGK-UPG \\
\hline
\end{tabular}

Sumber : https://www.wego.co.id

Tabel 6. Frekuensi Batik Air rute UPG-CGK Tahun 2019

\begin{tabular}{cccc}
\hline AIRLINES & TYPE AIRCRAFT & DAYS OPERATION & SCHEDULLE \\
\hline ID 6198 & B737-800 & $1,2,3,4,5,6,7$ & UPG-CGK \\
\hline ID 6182 & B737-800 & $1,2,3,4,5,6,7$ & UPG-CGK \\
\hline ID 6236 & B737-800 & $1,2,3,4,5,6,7$ & UPG-CGK \\
\hline ID 6296 & B737-800 & $1,2,3,4,5,6,7$ & UPG-CGK \\
\hline ID 6266 & B737-800 & $1,2,3,4,5,6,7$ & UPG-CGK \\
\hline
\end{tabular}

Sumber : https://www.wego.co.id

Frekuensi penerbangan dapat dilihat dari banyaknya jumlah keberangkatan dan kedatangan suatu pesawat terbang dari suatu Bandar udara pada setiap harinya. Perkembangan Batik Air seiring dengan laju perkembangan ekonomi, untuk rute CGK-UPG. Batik Air melakukan penerbangan rute CGK-UPG dalam seminggu sebanyak 35 kali yaitu pada hari senin, selasa, rabu, kamis, jumat, sabtu, dan minggu dengan menggunakan tipe pesawat B737-800NG, sehingga total frekuensi untuk tiga bulan 35/7x92 hari adalah 460 kali. Dalam pembahasan menggunakan tipe pesawat B737-800NG dengan asumsi melakukan penerbangan dengan jumlah frekuensi yang sama yaitu sebanyak 35 kali dalam seminggu atau $460 \mathrm{flight} / 3 \mathrm{bulan}$. Demikian juga untuk penerbangan Batik Air rute UPG-CGK sama.

Tabel 7. Frekuensi Citilink rute CGK-UPG Tahun 2019

\begin{tabular}{cccc}
\hline AIRLINES & TYPE AIRCRAFT & DAYS OPERATION & SCHEDULLE \\
\hline QG 340 & B737-800 & $1,2,3,4,5,6,7$ & CGK-UPG \\
\hline QG 332 & B737-800 & $1,2,3,4,5,6,7$ & CGK-UPG \\
\hline QG 426 & B737-800 & $1,2,3,4,5,6,7$ & CGK-UPG \\
\hline QG 212 & B737-800 & $1,2,3,4,5,6,7$ & CGK-UPG \\
\hline QG 250 & B737-800 & $1,2,3,4,5,6,7$ & CGK-UPG \\
\hline
\end{tabular}

Sumber : $\underline{\text { https://www.wego.co.id }}$

Tabel 8. Frekuensi Citilink rute UPG-CGK Tahun 2019

\begin{tabular}{cccc}
\hline AIRLINES & TYPE AIRCRAFT & DAYS OPERATION & SCHEDULLE \\
\hline QG 340 & B737-800 & $1,2,3,4,5,6,7$ & UPG-CGK \\
\hline QG 332 & B737-800 & $1,2,3,4,5,6,7$ & UPG-CGK \\
\hline QG 426 & B737-800 & $1,2,3,4,5,6,7$ & UPG-CGK \\
\hline QG 212 & B737-800 & $1,2,3,4,5,6,7$ & UPG-CGK \\
\hline QG 250 & B737-800 & $1,2,3,4,5,6,7$ & UPG-CGK \\
\hline
\end{tabular}

Sumber : https://www.wego.co.id

Frekuensi penerbangan dapat dilihat dari banyaknya jumlah keberangkatan dan kedatangan suatu pesawat terbang dari suatu Bandar udara pada setiap harinya. Perkembangan Citilink seiring dengan laju perkembangan ekonomi, untuk rute CGK-UPG. Citilink melakukan penerbangan rute CGK-UPG dalam seminggu sebanyak 35 kali yaitu pada hari senin, selasa, rabu, kamis, jumat, sabtu, dan minggu dengan menggunakan tipe pesawat 
B737-800NG, sehingga total frekuensi untuk tiga bulan 35/7x92 hari adalah 460 kali. Dalam pembahasan ini penulis menggunakan tipe pesawat B737-800NG dengan asumsi melakukan penerbangan dengan jumlah frekuensi yang sama yaitu sebanyak 35 kali dalam seminggu atau 460 flight $/ 3$ bulan. Demikian juga untuk penerbangan Citilink rute UPG-CGK sama.

Tabel 9. Frekuensi Sriwijaya Air Rute CGK-UPG Tahun 2019

\begin{tabular}{cccc}
\hline AIRLINES & TYPE AIRCRAFT & DAYS OPERATION & SCHEDULLE \\
\hline SJ 588 & B737-800 & $1,2,3,4,5,6,7$ & CGK-UPG \\
\hline SJ 584 & B737-800 & $1,2,3,4,5,6,7$ & CGK-UPG \\
\hline
\end{tabular}

Sumber : https://www.wego.co.id

Tabel 10. Frekuensi Sriwijaya Air Rute UPG-CGK Tahun 2019

\begin{tabular}{cccc}
\hline AIRLINES & TYPE AIRCRAFT & DAYS OPERATION & SCHEDULLE \\
\hline SJ 588 & B737-800 & $1,2,3,4,5,6,7$ & UPG-CGK \\
\hline SJ 584 & B737-800 & $1,2,3,4,5,6,7$ & UPG-CGK \\
\hline
\end{tabular}

Sumber : https://www.wego.co.id

Frekuensi penerbangan dapat dilihat dari banyaknya jumlah keberangkatan dan kedatangan suatu pesawat terbang dari suatu Bandar udara pada setiap harinya. Perkembangan Sriwijaya Air seiring dengan laju perkembangan ekonomi, untuk rute CGK-UPG. Sriwijaya Air melakukan penerbangan rute CGK-UPG dalam seminggu sebanyak 14 kali yaitu pada hari senin, selasa, rabu, kamis, jumat, sabtu, dan minggu dengan menggunakan tipe pesawat B737-800NG, sehingga total frekuensi untuk tiga bulan 14/7x92 hari adalah 184 kali. Dalam pembahasan ini penulis menggunakan tipe pesawat B737-800NG dengan asumsi melakukan penerbangan dengan jumlah frekuensi yang sama yaitu sebanyak 14 kali dalam seminggu atau 184 flight $/ 3$ bulan. Demikian juga untuk penerbangan Sriwijaya Air rute UPG-CGK sama. Berdasarkan data frekuensi flight setiap airline maka penulis dapat membuat frekuensi sharenya. Dibawah ini adalah tabel frekuensi flight selama 3 bulan setiap airline :

Tabel 11. Frekuensi Flight Airline selama 3 bulan Rute UPG-CGK Tahun 2019

\begin{tabular}{cc}
\hline Airline & Frekuensi flight 3 bulan \\
\hline Garuda & 607 \\
\hline Lion Air & 552 \\
\hline Batik Air & 460 \\
\hline Citilink & 460 \\
\hline Sriwijaya Air & 184 \\
\hline \multicolumn{2}{l}{ Sumber : Data Diolah oleh penulis }
\end{tabular}

Dengan di ketahuinya frekuensi flight setiap airline maka penulis dapat mengetahui frekuensi share dari setiap airline.

1. Garuda = F Garuda : total F X $100 \%$

$$
\begin{aligned}
& =578: 2234 \times 100 \% \\
& =25 \%
\end{aligned}
$$

2. Lion Air = F Lion Air : total F X $100 \%$

$$
\begin{aligned}
& =552: 2234 \times 100 \% \\
& =24 \%
\end{aligned}
$$

3. Batik Air = F Batik Air : total F X 100\%

$$
=460: 2234 \times 100 \%
$$$$
=20 \%
$$

4. Citilink = F Citilink : total F X 100\%

$$
\begin{aligned}
& =460: 2234 \times 100 \% \\
& =20 \%
\end{aligned}
$$

5. Sriwijaya Air = F Sriwijaya Air : total F X $100 \%$

$$
=184: 2234 \times 100 \%
$$


$=8 \%$

\section{Frekuensi Share Airline}

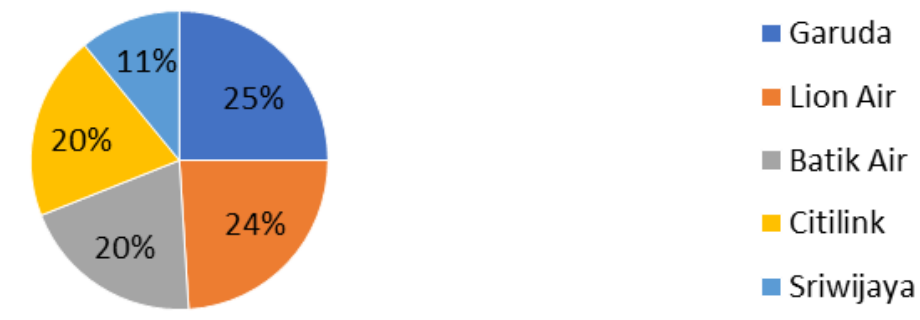

Gambar 2. Diagram Frekuensi Share

Data : di olah oleh penulis

Dari hasil di atas penulis dapat mengetahui masing masing data frekuensi flight setiap airline yakni : Garuda $=25 \%$, Lion Air $=24 \%$, Batik Air $=20 \%$, Citilink $=20 \%$, dan Sriwijaya $=11 \%$. Dalam penelitian ini hanya memfokuskan di airline Garuda saja. Adapun data statistic penumpang yang melakukan perjalanan dengan rute Jakarta - Makassar sebagai berikut ini :

Tabel 12. Total Passanger Airline rute Jakarta - Makassar PP selama 3 Bulan Tahun 2019

\begin{tabular}{cccc} 
Type Pesawat & October & November & December \\
\hline Garuda Indonesia & 64439 & 65881 & 55946 \\
\hline Lion Air & 91107 & 68407 & 62068 \\
\hline Batik Air & 65363 & 50387 & 37994 \\
\hline Citilink & 32502 & 40762 & 38991 \\
\hline Sriwijaya & 26652 & 29860 & 27737 \\
\hline Other & 3460 & 3322 & 2935
\end{tabular}

Sumber : PT. Garuda Indonesia

Dari data di atas penulis mendapatkan total jumlah penumpang selama 3 bulan untuk maskapai Garuda $=$ 186.266 Pax, Lion Air $=221.582$ Pax, Batik Air $=153.744$ Pax, Citilink $=112.255$ Pax, Sriwijaya $=84.249$ Pax, dan Other $=9.717$ Pax.

Dengan demikian penulis dapat mengetahui passanger share setiap airline

1. Garuda = Pax garuda : total Pax X $100 \%$

$$
\begin{aligned}
& =186.266: 767.813 \times 100 \% \\
& =24 \%
\end{aligned}
$$

2. $\quad$ Lion Air $=$ Pax Lion Air : total Pax X $100 \%$

$$
\begin{aligned}
& =221.582: 767.813 \times 100 \% \\
& =28 \%
\end{aligned}
$$

3. Batik Air $=$ Pax Batik Air : total Pax X $100 \%$

$=153.744: 767.813 \times 100 \%$

$=20 \%$

4. Citilink = Pax Citilink : total Pax X 100\%

$=112.255: 767.813 \times 100 \%$

$$
=14 \%
$$

5. Sriwijaya $=$ Pax Sriwijaya : total Pax X $100 \%$

$$
=84249: 767.813 \times 100 \%
$$

$=13 \%$

6. Other = Pax Other : total Pax X 100\% 


$$
\begin{aligned}
& =9717: 767.813 \\
& =1 \%
\end{aligned}
$$

Di bawah ini merupakan diagram lingkaran passanger share semua airlines

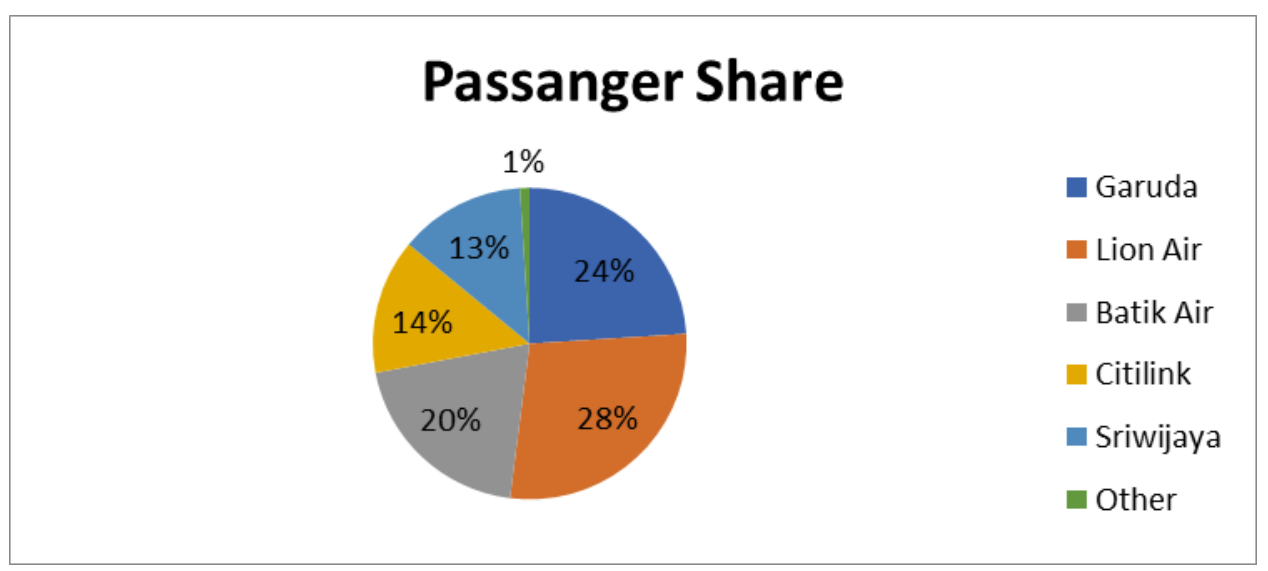

\section{Gambar 3. Diagram Passanger Share}

Sumber : Data di olah oleh penulis

Dari diagram diatas penulis mendapatkan total Passanger Share selama 3bulan untuk maskapai Garuda Indonesia $=24 \%$, Lion Air $=28 \%$, Batik Air $=20 \%$, Citilink $=14 \%$, Sriwijaya $=13 \%$, dan other $=1 \%$.

Jam Terbang, dihitung berdasarkan dari block time. Dimana block time adalah waktu yang diperlukan untuk satu stop penerbangan dari satu tempat ketempat lain yang dihitung sejak mesin dihidupkan (block on) pada saat keberangkatan sampai dengan mesin dimatikan (block off) pada saat kedatangan. dibawah ini menunjukan block time rute penerbangan Garuda Indonesia yang akan dijadikan dasar dalam menghitung biaya operasi untuk penerbangan CGK - UPG PP.

Tabel 13. Data rute Penerbangan CGK-UPG Untuk 2019 Garuda Indonesia

\begin{tabular}{cccccc} 
Dari & Ke & Jarak NM & Jarak KM & Type Aircraff & Block Time \\
& & & & & \\
\hline CGK & UPG & 828 & 1.533 & B737-800 & 02.30 \\
\hline UPG & CGK & 802 & 1.485 & B737-800 & 02.45 \\
\hline
\end{tabular}

Sumber : Data diolah oleh penulis

Pada tabel di tas merupakan rute penerbangan CGK-UPG pada tahun 2019 menggunakan tipe pesawat B737-800 dengan jarak tempuh dari CGK-UPG 828NM, sedangkan jarak tempuh UPG - CGK 802NM. Karakteristik B737-800NG, Data karakteristik pesawat merupakan data - data yang dikeluarkan oleh pabrik (manufacture) dan sebagai bahan perhitungan dasar masing-masing pesawat bagi operator (airlines/air character). Karakteristik pesawat yang digunakan disajikan pada Tabel 4.14.

\begin{tabular}{|c|c|}
\hline A/C Type & B 737-800NG \\
\hline Engine Type & CFM 56-7B26 \\
\hline \multicolumn{2}{|c|}{ Seat Conf. } \\
\hline Passenger & $12 \mathrm{C} / 162 \mathrm{Y}$ \\
\hline Crew & 2 Pilots \& 6 Flight Attendants \\
\hline \multicolumn{2}{|c|}{ Dimensions } \\
\hline Overall Length & $39.47 \mathrm{~m}$ \\
\hline Height & $12.5 \mathrm{~m}$ \\
\hline Wing Span & $35.78 \mathrm{~m}$ \\
\hline \multicolumn{2}{|c|}{ Aircraft Structure } \\
\hline DOW & $44.624 \mathrm{~kg}$ \\
\hline
\end{tabular}

Table 14. Spesifikasi Pesawat B 737-800NG PT. Garuda Indonesia 


\begin{tabular}{|c|c|c|}
\hline MZFW & \multicolumn{2}{|c|}{$61.688 \mathrm{~kg}$} \\
\hline MTOW & \multicolumn{2}{|c|}{$79.015 \mathrm{~kg}$} \\
\hline MLW & \multicolumn{2}{|c|}{$65.317 \mathrm{~kg}$} \\
\hline Maximum Payload & \multicolumn{2}{|c|}{$17.064 \mathrm{~kg}$} \\
\hline \multicolumn{3}{|c|}{ Performance } \\
\hline Range & \multicolumn{2}{|c|}{$3.059 \mathrm{NM}$} \\
\hline \multirow[t]{2}{*}{ Speed } & Cruising Speed & Maximum Speed \\
\hline & M 0.79 & M 0.82 \\
\hline \multicolumn{3}{|c|}{ Takeoff Field (Sea Level, ISA) } \\
\hline Takeoff Distance at MTOW & \multicolumn{2}{|c|}{$2.522 \mathrm{~m}$} \\
\hline Minimum Landing Distance & \multicolumn{2}{|c|}{$1.538 \mathrm{~m}$} \\
\hline
\end{tabular}

Sumber: PT Garuda Indonesia

Berdasarkan data pada Tabel 12 diatas dapat dijelaskan sebagai berikut: Pesawat B 737-800NG ini menggunakan mesin twinjet turbofan dengan menggunakan tipe mesin CFM56-7B26, mesin ini telah di kembangkan untuk Next-Generation 737 operator dengan daya dorong yang lebih tinggi, peningkatan efisiensi, dan biaya pemeliharaan lebih rendah dari pada pendahulunya yaitu CFM56-3. Crew pesawat ini terdiri dari 1 set Cockpit Crew yaitu 1 Captain dan 1 Co-pilot serta 1 set Cabin Crew yaitu 6 Flight Attendants, terdapat 2 kelasyaitu 12 seat untuk Bisnis dan 162 seat untuk Ekonomi. Keseluruhan panjang dari pesawat B 737-800NG iniyaitu $39.47 \mathrm{~m}$, dengan tinggi $12.5 \mathrm{~m}$, dan lebar sayap sepanjang $35.78 \mathrm{~m}$. Adapun daya angkutnya dengan Dry Operating Weight (DOW) seberat 44,624 kg, Maximum Zero Fuel Weight (MZFW) seberat 61,688 kg, Maximum Take Off Weight (MTOW) seberat 79,015 kg, Maximum Landing Weight (MLW) seberat 65,317 $\mathrm{kg}$, dan Maximum Payload seberat $17.065 \mathrm{~kg}$. Sedangkan performa pesawat ini mempunyai jarak penerbangan sejauh 3,059 NM dengan Cruising Speed M 0.79 mencapai tingkat maximum sebesar M 0.82, dengan Takeoff Distance at MTOW sepanjang 2,522 m pada suhu 30oC dan Minimum Landing Distance sepanjang 1,538 m.

Load Factor, Indicator keberhasilan suatu perusahaan penerbangan biasanya menggunakan parameter load factor. Load factor ini terbagi menjadi dua macam yaitu weight load factor dan seat load factor, Weight load factor adalah ratio antara jumlah total berat yang diangkut (weight sold) dikali jarak dengan total jumlah kapasitas berat yang tersedia (payload dikali jarak). Sedangkan pax load factor (PLF) adalah ratio perbandingan antara jumlah tempat duduk yang terjual (seat sold) dikali jarak dengan jumlah seat yang tersedia (saleable seat) dikali jarak dan biasanya dalam bentuk presentase, Variabel yang mempengaruhi jumlah penumpang adalah diantaranya terdorong karena adanya tawaran harga yang bersaing, pelayanan yang baik, promosi yang gencar, banyaknya pilihan jadwal, frekuensi yang sesuai dengan kebutuhan calon penumpang, maupun tipe pesawat yang digunakan. Analisis Frekuensi Dengan Menggunakan Pesawat B737-800NG Rute CGK - UPG PP Tahun 2019, Pada analisis frekuensi dengan menggunakan tipe pesawat B737-800NG rute CGK-UPG PP, total frekuensi dalam 3 bulan menggunakan tipe pesawat B737-800NG sebanyak 607 flight, Dalam mengolah data muatan per flight asumsi pax load factor yang digunakan untuk tipe pesawat B737-800 NG sebesar 87,9\%. Berikut ini adalah tabel 4.15 data muatan tipe pesawat B737-800NG.

Tabel 15. Analisa Data Muatan B737 - 800NG Rute CGK - UPG dan UPG - CGK Per Flight

\begin{tabular}{ll}
\hline ITEM & B737-800NG \\
\hline Maximum Payload & $17.064 \mathrm{Kg}$ \\
\hline Kapasitas seat & $174 \mathrm{Seat}=12 \mathrm{C} / 162 \mathrm{Y}$ \\
\hline SBW & $85 \mathrm{Kg}$ \\
\hline Kapasitas seat X SBW & $14790 \mathrm{Pax}$ \\
\hline Pax per 3 bulan & $93.133 \mathrm{Pax}$ \\
\hline Frekuensi per 3 bulan & $607 \mathrm{Flight}$ \\
\hline Pax per Flight & $153 \mathrm{Pax}$ \\
\hline Cargo per 3 bulan & $607.000 \mathrm{Kg}$ \\
\hline Asumsi Cargo per Flight & $1.000 \mathrm{Kg}$ \\
\hline
\end{tabular}




\begin{tabular}{ll}
\hline Excess Baggage per 3 bulan & $12.140 \mathrm{Kg}$ \\
\hline Excess Baggage per Flight & $20 \mathrm{Kg}$ \\
\hline PLF per Fight & $87,9 \%$ \\
\hline WLF per Flight & $79 \%$ \\
\hline \multicolumn{2}{c}{ Sumber : Data diolah oleh penulis }
\end{tabular}

Berdasarkan data yang telah diolah pada tabel 4.15 diatas untuk penggunaan pesawat B737-800NG CGK - UPG dan UPG - CGK dengan frekuensi periode 3 bulan dapat dijelaskan sebagai berikut :1) Pax per flight, Dengan frekuensi 607 flight, rata-rata penumpang yang diangkut oleh B737-800NG adalah sebanyak 153 pax per flight, 2) PLF per flight Jumlah dari pax load factor (PLF) per flight yang diangkut oleh tipe pesawat B737800NG sebanyak 87,9\%, 3) Cargo per Flight, Berdasarkan data tersebut, kargo/flight adalah 1000Kgs/flight. Cargo dalam 3 bulan dibagi dengan frekuensi (607) dari total $607.000 \mathrm{Kgs}$, 4) Excess Baggage per flight, Pada data excess baggage per flight nya sama yaitu $20 \mathrm{Kgs}$. Dalam 3 bulan excess baggage memiliki total yaitu sebesar $12.140 \mathrm{~kg}$, karena diasumsikan per flight nya yaitu $20 \mathrm{~kg}$, 5) WLF per flight Jadi WLF per flight penggunaan tipe pesawat B737-800NG mencapai $79 \%$.

Cost untuk Penerbangan CGK - UPG PP B737-800NG Tahun 2019, Dalam pembahasan Cost dan Revenue untuk rute CGK - UPG PP Tahun 2019 dengan menggunakan pesawat Garuda B737-800NG, penulis membatasi hanya pada revenue yang berasal dari penumpang, excess baggage, dan cargo. Sedangkan pada pembahasan biaya penulis menggunakan rincian berdasarkan pembagian biaya operasi langsung dan tidak langsung. Biaya operasi langsung ini terdiri atas dua yaitu biaya operasi langsung tetap dan biaya operasi langsung variabel. Dimana biaya-biaya ini berpengaruh terhadap pengoperasian pesawat udara rute CGK UPG PP pada Garuda Indonesia Airlines, Asumsi biaya yang digunakan oleh penulis dalam analisis ini, sesuai dengan biaya untuk tipe pesawat yang digunakan pada rute UPG - CGK pada Garuda Indonesia Airlines. Pesawat yang digunakan adalah B737-800NG. Dengan asumsi data penulis tidak ada perubahaan adapun alokasi biaya untuk pesawat adalah sebagai berikut, Alokasi Biaya Operasi Pesawat B737-800NG Rute CGKUPG Dikarenakan harga bahan bakar berfluktuasi sesuai dengan nilai tukar Dollar, maka dalam penelitian ini digunakan asumsi bahwa harga bahan bakar Avtur adalah tetap yaitu dengan harga pada tahun 2019 sebesar Rp.9.550 atau US \$0,68 per litter dengan kurs 1 US\$ = Rp.14.000, Dibawah ini merupakan Tabel 4.17 Alokasi Biaya Pesawat B737-800NG Rute CGK - UPG PP Per Flight Pada PT. Garuda Indonesia

Tabel 16. Alokasi Biaya Pesawat B737-800NG Rute CGK-UPG PP Per Flight pada PT. Garuda Indonesia

\begin{tabular}{lcc}
\hline Cost & CGK-UPG/FLIGHT & UPG-CGK/FLIGHT \\
\cline { 2 - 3 } Direct Traffic Costs & & \\
\hline Passenger Commission & 975 & $1.177,8$ \\
\hline Freight Commission & 195 & 235,56 \\
\hline Credit Card Commission & 585 & 706,68 \\
\hline Catering & 780 & 780 \\
\hline On Board Sevice & 60,56 & 64,68 \\
\hline Reservation & 1187,32 & 1207,49 \\
\hline Total Direct Traffic Costs & $\mathbf{3 . 7 8 2 , 8 8}$ & $\mathbf{4 . 1 7 2 , 2 1}$ \\
\hline Direct Flight Cost & & $70001 \mathrm{lt} \times 0,68=4760$ \\
\hline Fuel Aircraft & $70001 \mathrm{x} 0,68=4760$ & 47,33 \\
\hline Landing & 47,33 & 651,91 \\
\hline Handling & 651,91 & 236,54 \\
\hline Air Traffic Control & 230,20 & 447,24 \\
\hline Cockpit Crew Travel & 425,21 & 485,99 \\
\hline Cabin Crew Travel & 471,54 & 1507,32 \\
\hline Variable Maintenance & 1388,89 & $\mathbf{8 . 1 3 6 , 3 3}$ \\
\hline Total Direct Flight Costs & $\mathbf{7 . 9 7 5 , 0 8}$ & $12.308,54$ \\
\hline Total Direct Costs & $11.757,96$ & \\
\hline Indirect Costs & & \\
\hline
\end{tabular}




\begin{tabular}{lcc}
\hline Cockpit Crew Person & 350,30 & 372,85 \\
\hline Cabin Crew Person & 134,45 & 138,39 \\
\hline Air Craft Maintenance & 38,68 & 41,93 \\
\hline Total Indirect Costs & $\mathbf{5 2 3 , 4 3}$ & $\mathbf{5 3 7 , 4 4}$ \\
\hline Total Direct And Indirect Costs & $12.281,39$ & 12.84598 \\
\hline Fleet Costs & & \\
\hline Depreciation Air Craft & 357,67 & 383,27 \\
\hline Lease Aircraft & 3116,69 & 3357,58 \\
\hline Insurance & 35,98 & 37,60 \\
\hline Total Fleet Costs & $\mathbf{3 5 1 0 , 3 4}$ & $\mathbf{3 6 6 9 , 8 8}$ \\
\hline Total Direct, Indirect, Fleet Costs & $15.791,73$ & $16.515,86$ \\
\hline Overhead Cost & 283,71 & 214,98 \\
\hline Station & 363,14 & 383,31 \\
\hline Sales Oerganization & 229,27 & 235,98 \\
\hline Marketing & 49,74 & 48,55 \\
\hline Administration Bo & 144,08 & 339,94 \\
\hline Flight Interrupted & 10,31 & 48,88 \\
\hline Total Overhead & 1080,25 & $1.271,64$ \\
\hline Total Cost & $16.871,98$ & $17.787,5$ \\
\hline St: PT. Garta & &
\end{tabular}

Sumber : PT. Garuda Indonesia, diolah penulis

Berikut ini adalah tabel 15 Revenue pesawat B737-800NG rute CGK-UPG per 3bulan dengan estimasi load factor B737-800NG sebesar 87,9, Revenue untuk Penerbangan CGK - UPG PP B737-800NG Tahun 2019.

Tabel 17. Revenue Pesawat B737-800NG Rute CGK-UPG Per 3bulan pada PT. Garuda Indonesia

\section{Total pax per 3bulan Tariff Rata - Rata B737-800NG}

\begin{tabular}{llll}
\hline Pax & 93.133 & US\$ 125 & US\$ 11.641.625 \\
\hline Cargo & 607.000 & US\$ 1 & US\$ 607.000 \\
\hline Exc. Bagagge & 12.140 & US\$ 2 & US\$ 24.280 \\
\hline Total Revenue & & US\$ 12.272.905 \\
\hline Sumber: Data diolah oleh penulis &
\end{tabular}

Dari tabel 15 diatas dapat dilihat total pendapatan passanger selama 3 bulan untuk rute CGK - UPG dengan penggunaan tipe pesawat B737 - 800NG yaitu sebesar US\$ 11.641 .625 sehingga untuk total keseluruhan termasuk cargo dan exc. Baggage selama 3 bulan menjadi sebesar US\$ 12.272.905. Penetapan tariff dalam tabel revenue di atas penulis menetapkan tariff berdasarkan tariff rata-rata pelayanan kelas ekonomi rute CGK - UPG sebesar Rp 1.750 .000 atau US\$ 125. Penulis mengasumsikan untuk tariff cargo sebesar US\$ 1 dan exc baggage sebesar US\$2. Sedangkan pada tabel 16 Revenue pesawat B737 - 800 rute UPG - CGK per 3 bulan dengan estimasi load factor B737-800NG sebesar 87,9\%.

Tabel 18. Revenue Pesawat B737-800NG Rute UPG-CGK Per 3 bulan pada PT. Garuda Indonesia

$$
\text { Total pax per } 3 \text { bulan } \quad \text { Tariff Rata-Rata } \quad \text { B737-800 }
$$

\begin{tabular}{llll}
\hline Pax & 93.133 & US\$ 151 & US\$ 14.063.083 \\
\hline Cargo & 607.000 & US\$ 1 & US\$ 607.000 \\
\hline Exc. Bagagge & 12.140 & US\$ 2 & US\$ 24.280 \\
\hline Total Revenue & & US\$ 14.694.363 \\
\hline
\end{tabular}

Sumber: Data diolah oleh penulis 
Pada tabel 15 diatas dapat diketahui total pendapatan passanger selama 3 bulan untuk rute UPG-CGK dengan penggunaan tipe pesawat B737-800NG yaitu sebesar US\$14.063.083 sedangkan untuk total keseluruhan termasuk cargo dan exc. Baggage selama 3 bulan sebesar US\$ 14.694.363. Penetapan tariff dalam tabel revenue di atas penulis menetapkan tariff berdasarkan tariff rata- rata pelayanan kelas ekonomi rute UPG - CGK sebesar Rp 2.114.000 atau US\$ 151, lebih mahal US\$26 dibandingkan tarrif CGK - UPG yang sebesar US\$125. Penulis mengasumsikan untuk tariff cargo sebesar US\$ 1 dan exc baggage sebesar US\$ 2.

Di bawah ini adalah tabel 16merupakan perhitungan Biaya Pesawat B737-800NG Rute CGK-UPG PP Per 3 Bulan Pada PT. Garuda Indonesia.

Tabel 19. Alokasi Biaya Pesawat B737-800 Rute CGK-UPG PP Per 3 Bulan pada PT. Garuda Indonesia

\begin{tabular}{lll}
\hline Cost & CGK-UPG/3 Bulan & UPG-CGK/3 Bulan \\
\cline { 2 - 3 } Direct Traffic Costs & & \\
\hline Passenger Commission & 591.825 & $714.824,6$ \\
\hline Freight Commission & 118.365 & $142.984,92$ \\
\hline Credit Card Commission & 355.095 & $428.954,76$ \\
\hline Catering & 473.460 & 473.460 \\
\hline On Board Sevice & $36.759,92$ & $39.260,76$ \\
\hline Reservation & $720.703,24$ & $732.946,43$ \\
\hline Total Direct Traffic Costs & $2.296 .208,16$ & $2.532 .431,47$ \\
\hline Direct Flight Cost & & \\
\hline Fuel Aircraft & 2.889 .320 & 2.889 .320 \\
\hline Landing & $28.729,31$ & $28.729,31$ \\
\hline Handling & $395.709,37$ & $395.709,37$ \\
\hline Air Traffic Control & $139.731,4$ & $143.579,78$ \\
\hline Cockpit Crew Tr'avel & $258.102,47$ & $271.474,68$ \\
\hline Cabin Crew Travel & $286.224,78$ & $294.995,93$ \\
\hline Variable Maintenance & $843.056,23$ & $914.943,24$ \\
\hline Total Direct Flight Costs & $4.840 .973,56$ & $4.938 .752,31$ \\
\hline Total Direct Costs & $7.137 .081,72$ & $7.471 .183,78$ \\
\hline Indirect Costs & & \\
\hline Cockpit Crew Person & $212.632,1$ & $226.319,95$ \\
\hline Cabin Crew Person & $81.611,15$ & $84.002,73$ \\
\hline Air Craft Maintenance & $23.478,76$ & $25.451,51$ \\
\hline Total Indirect Costs & $317.722,01$ & $335.774,19$ \\
\hline Total Direct And Indirect Costs & $7.454 .803,73$ & $7.806 .957,97$ \\
\hline Fleet Costs & & \\
\hline Depreciation Air Craft & $217.105,69$ & $232.644,89$ \\
\hline Lease Aircraft & $1.891 .830,83$ & $2.038 .051,06$ \\
\hline Insurancel & $21.839,86$ & $22.823,2$ \\
\hline Total Fleet Costs & $2.130 .776,38$ & $2.293 .519,15$ \\
\hline Total Direct, Indirect, Fleet Costs & $9.585 .580,11$ & $10.100 .447,12$ \\
\hline Overhead Cost & $172.211,97$ & $130.492,86$ \\
\hline Station & $220.425,98$ & $232.669,17$ \\
\hline Sales Organization & $139.166,89$ & $143.239,86$ \\
\hline Marketing & $30.192,18$ & $29.469,85$ \\
\hline Administration Bo & $87.456,56$ & $206.343,58$ \\
\hline Flight Interrupted & $6.258,17$ & $771.885,48$ \\
\hline Total Overhead & $656.925,75$ & $10.872 .332,6$ \\
\hline Total Cost & $10.242 .505,86$ & \\
\hline \hline & & \\
\hline Per: PT. Gata & & \\
\hline
\end{tabular}

Sumber: PT. Garuda Indonesia, diolah penulis 
Dibawah ini adalah Tabel 4.20 Profitabilitas pesawat B737-800NG Rute CGK - UPG dan UPG - CGK Tahun 2019

Tabel 20. Profitabilitas B737-800NG Rute CGK - UPG PP Tahun 2019

\begin{tabular}{lll}
\hline RUTE & CGK - UPG & UPG - CGK \\
\hline Total Revenue & US\$ 12.262 .505 & US\$ 14.683.963 \\
\hline Total Cost & US $\$ 10.242 .505$ & US\$ $10.872 .332,60$ \\
\hline Total Profit & US $\$ 2.030 .399,14$ & US\$ $3.822 .030,40$ \\
\hline
\end{tabular}

Sumber: Data Diolah Penulis

Passanger Commission, asumsikan 5\% dari tariff rata-rata rute CGK - UPG sehingga passanger commission yang dikeluarkan selama 3 bulan adalah sebesar US\$ 591.825, Freight Commission, asumsikan per 3bulan Freight Commission rute CGK - UPG sebesar US\$ 195 dengan demikian Freight Commision yang dikeluarkan akan dibayarkan selama 3bulan yaitu US\$195 dikali frekuensi flight per 3bulan = US\$195 X 607 = US\$ 118.365 Per 3bulan, Credit Card Commision, asumsikan per 3bulan Credit Card Commission rute CGK - UPG sebesar US\$ 585 dengan demikian Credit Card Commision yang dibayarkan selama 3bulan yaitu US\$ 585 dikali frekuensi flight per 3bulan = US\$ 585 X $607=$ US\$ 355.095 Per 3bulan, Catering, Catering yang dihasilkan per flight yaitu US\$ 780 dengan demikian biaya catering yang dikeluarkan selama 3 bulan sebesar US\$ 473.460 hasil tersebut di dapatkan dari biaya catering per flight di kali dengan frekuensi 3 bulan, On Board Service, dengan demikian On Board Service yang dikeluarkan selama 3bulan sebesar US\$36.759,92 , hasil tersebut didapatkan dari biaya on board service per flight di kalikan frekuensi selama 3 bulan. Reservation, dengan demikian biaya Reservation yang dikeluarkan selama 3bulan sebesar US\$ 720.703,24 hasil tersebut didapatkan dari biaya reservation per flight di kali frekuensi selama 3 bulan. Fuel Aircraft, dengan demikian fuel aircraft yang dikeluarkan selama 3bulan yaitu US\$ 4760 dikali frekuensi flight per 3 bulan $=$ US\$ 4760 X $607=$ US\$2.889.320 Per 3bulan. Landing, Landing adalah biaya pendaratan. Untuk biaya landing per flight adalah US\$ 47,33 angka tersebut di dapatkan dari MTOW B737-800NG 79 Ton perhitungan setiap 40 Ton sampai 100 Ton kena tariff sebesar IDR 312.035 maka landing fee $=312.035+$ $8.900 /$ Ton X $(79-40)=312.035+350.610=$ IDR 662.645 atau US $\$ 47,33$ jadi biaya landing selama 3 bulan yaitu US\$ 47,33 dikali frekuensi flight per 3bulan= US\$ 47,33 X $607=$ US\$28.729,31 Per 3bulan. Handling, Untuk biaya handling diasumsikan per flight US\$ 651,91 jadi biaya handling selama 3bulan yaitu US\$ 651,91 dikali frekuensi flight per 3bulan = US\$ 651,91X $607=$ US\$ 395.709,37 Per 3bulan. Air Traffic Control, asumsikan per flight Air Traffic Control yaitu US\$230,20 dengan demikian biaya Air Traffic Control yang dihasilkan selama 3bulan yaitu US\$230,20 dikali frekuensi flight per 3 bulan = US\$230,20 X $607=$ US\$ 139.792,1 Per 3bulan.

Cockpit Crew Travel, asumsikan biaya cockpit crew per flight yaitu US\$ 425,21 jadi biaya cockpit crew selama 3bulan yaitu US\$ 425,21 dikali frekuensi flight per 3bulan = US\$ 425,21 X $607=$ US\$258.102,47 Per 3bulan, Cabin Crew Travel, Di asumsikan per flight sebesar US\$ 471,54 jadi biaya cabin crew selama 3bulan yaitu US\$ 471,54 dikali frekuensi flight per 3bulan = US\$ 471,54 X $607=$ US\$ 286.224,78 Per 3bulan, Variabel maintenance, Variabel Maintenance adalah biaya pemeliharaan dan perbaikan pesawat. Biaya penggunaan tipe pesawat B737-800 per flight US\$1.388,89 jadi total biaya variabel selama 3bulan yaitu US\$ 1388,89 di kali frekuensi flight per 3bulan = US\$1.388,89 X $607=$ US\$ 843.056,23 Per 3bulan.

Cockpit Crew Person, Cockpit Crew Person adalah gaji yang diterima oleh seorang cockpit crew per flight US \$ 350,30 jadi total biaya cockpit crew person selama 3bulan yaitu US\$ 350,30 dikali frekuensi flight per 3bulan = US\$ 350,30 X $607=$ US\$212.632,1 Per 3bulan, Cabin Crew Person, Cabin Crew Person adalah gaji yang diterima oleh seorang Cabin crew per flight US\$134,45 jadi total biaya cockpit crew person selama 3bulan yaitu US\$134,45 dikali frekuensi flight per 3bulan = US\$134,45 X $607=$ US\$ 81.611,15 Per 3bulan, Aircraft Maintenance, Aircraft Maintenance adalah biaya perawatan pesawat per flight US\$38,68 jadi total biaya aircraft maintenance selama 3bulan yaitu US\$38,68 dikali frekuensi flight per 3bulan $=$ US\$ 38,68 X $607=$ US\$23.478,76 Per 3bulan.

Profititabilitas untuk rute Jakarta - Makassar PP B737-800 Tahun 2019, Dari seluruh data yang ditulis oleh penulis akhir nya penulis dapat membuat profitabilitas Rute Jakarta - Makassar PP dengan menggunakan pesawat Garuda B737-800NG Tahun 2019 selama 3 bulan Sebagai berikut : 
Diketahui Total Cost untuk Rute CGK - UPG sebesar US\$10.242.505,86, dan total cost untuk Rute UPG - CGK sebesar US\$ 10.872.332,6. Jadi total cost untuk rute CGK - UPG PP selama 3bulan menggunakan B737-800NG sebesar US\$21.114.838,46

Diketahui Total Revenue untuk Rute CGK - UPG sebesar US\$ 12.262.505, dan total Revenue untuk rute UPG - CGK sebesar US\$ 14.683.963. Jadi total revenue rute CGK - UPG PP selama 3bulan menggunakan B737-800NG sebesar US\$26.946.468.

Jadi total Profit untuk rute CGK - UPG PP selama 3bulan menggunakan B78-800NG adalah total revenue CGK - UPG PP dikurangi dengan total cost CGK - UPG PP = US\$26.967.268 dikurang dengan US\$ 21.114.838,46 = US\$5.852.429,54.

\section{KESIMPLAN DAN SARAN}

Kesimpulan bahwa penerbangan rute CGK - UPG PP Menggunakan tipe pesawat B737-800NG: 1) Pangsa pasar penerbangan rute CGK - UPG PP dikuasai oleh Garuda Untuk frekuensi sharnya sebesar 25\% sedangkan di market sharenya di kuasai oleh Lion air sebesar 28\%. Garuda dengan frekuensi share 25\% yang lebih tinggi dari Lion Air yang $24 \%$, namun perolehan market sharenya kalah bersaing dari Lion Air yaitu GA 24\% sedangkan JT 28\%, 2) Berdasarkan Tabel Cost 4.20 diatas penulis dapat menyimpulkan bahwa total cost untuk Rute CGK - UPG PP selama 3 bulan menggunakan B737-800NG sebesar US\$ 21.114.838,46. Berdasarkan Tabel Revenue 4.18 dan 4.19 diatas penulis dapat menyimpulkan bahwa total Revenue untuk Rute CGK - UPG PP selama 3 bulan menggunakan B737-800NG sebesar US\$ 26.967.268, 3) Berdasarkan Tabel Cost 4.20 diatas penulis dapat memyimpulkan bahwa total profit untuk Rute CGK - UPG PP selama 3 bulan menggunakan B737-800NG sebesar US\$ 5.852.429,54. 


\section{DAFTAR PUSTAKA}

Abdullah, T. dan F. T. (2017). Manajemen Pemasaran. PT Raja Grafindo Persada.

Assauri, S. (2015). Manajemen Pemasaran. PT Raja Grafindo Persada.

Brigham, E. . dan J. F. H. (2009). Dasar-dasar Manajemen Keuangan (10th ed.). Salemba Empat.

Dewi, S. P., Kristanto, S. B., \& Sermawan, E. S. (2015). Akutansi Biaya (2nd ed.). IN MEDIA.

Duari, I. P. H. H. (2018). Tiket Penerbangan Domestik (1 st ed.). DEEPUBLISH.

Kasmir. (2011). Analisis Laporan Keuangan. PT Raja Grafindo Persada.

Kasmir. (2014). Analisis Laporan Keuangan. PT Raja Grafindo Persada.

Medias, F. (2018). Ekonomi Makro Islam (UNNIMA PRESS (ed.); 1st ed.).

Mulyadi. (2016). Pengantar Manajemen (5th ed.). Unit Penerbit dan Percetakan Akademi Manajemen Perusahaan YKPN.

Nursalam. (2003). Konsep dan Penerapan Metodologi Penelitian. Salemba Medika.

Setiyaningrum, A., Udaya, J., \& E. (2015). Prinsip-Prinsip Pemasaran (1st ed.). ANDI Yogyakarta.

Siregar, S. (2013). Metode Penelitian Kuantitatif. PT Fajar Interpratama Mandiri.

Sugiyono. (2016). Metode Penelitian Kuantitatif, Kualitatif dan R\&D. PT Alfabet.

Sujarweni, V. W. (2019). Akuntansi Biaya. Pustaka Baru Press.

Sutrisno. (2009). Manajemen Keuangan Teori, Konsep dan Aplikasi (1st ed.). Ekonisia.

Weston, Fred dan Thomas, E. C. (2010). Manajemen Keuangan (2nd ed.). Binarupa Aksara Publisher.

Winarso, W. (2014). Pengaruh Biaya Operasional terhadap Profitabilitas PT Telkom (Persero) (2nd ed.). Jurnal Ecodemica.

Https://www.wego.co.id

\section{UNDANG - UNDANG DAN PERATURAN MENTERI}

KM 72 TAHUN 2019 tentang Tarif Batas Atas Penumpang Pelayaran Kelas Ekonomi Angkutan Udara Niaga Berjadwal

ARTIKEL JURNAL

Amin, A. P. (2013). Analisis Pengaruh Tarif Penerbangan, Jumlah Penerbangan Dan Pendapatan Perkapita Dalam Meningkatkan Jumlah Penumpang. Jurnal Bisnis Strategi, 22(1), 49-66. https://doi.org/10.14710/jbs.22.1.49-66

Pamungkas, S. W. H. (2019). Pengaruh Tarif, Citra Merek, dan Kualitas Pelayanan Terhadap Keputusan $\begin{array}{lllll}\text { Pembelian } & \text { Tiket } & \text { Maskapai } & \text { Penerbangan } & \text { Citilink. }\end{array}$ https://ejournal3.undip.ac.id/index.php/jiab/article/view/14559 